PERM JOURNAL OF PETROLEUM AND MINING ENGINEERING

ВЕСТНИК ПНИПУ. ГЕОЛОГИЯ. НЕФТЕГАЗОВОЕ И ГОРНОЕ ДЕЛО

ISSN 2224-9923

Volume / Tом 17 №2 2018

http://vestnik:pstu.ru/geo/

УДК 622.276 .05

Article / Статья

(c) PNRPU / ПНИПУ, 2018

\title{
ECOLOGICAL AND ECONOMIC EVALUATION OF QUARRY TROLLEY TRUCKS
}

\section{Mark L. Khazin, Aleksandr P. Tarasov ${ }^{1}$}

Ural State University of Mining (30 Kuybysheva st., Ekaterinburg, 620144, Russian Federation)

${ }^{1}$ Perspektiva-M LLC (87 Khokhryakova st., Ekaterinburg, 620144, Russian Federation)

\section{ЭКОЛОГО-ЭКОНОМИЧЕСКАЯ ОЦЕНКА КАРЬЕРНЫХ ТРОЛЛЕЙВОЗОВ}

\section{М.Л. Хазин, А.П. Тарасов ${ }^{1}$}

Уральский государственный горный университет (620144, Россия, г. Екатеринбург, ул. Куйбышева, 30)

${ }^{1} \mathrm{OOO}$ «Перспектива-М» (620144, Россия, г. Екатеринбург, ул. Хохрякова, 87)

Received / Получена: 17.04.2018. Accepted / Принята: 09.06.2018. Published / Опубликована: 29.06.2018

Key words:

quarry dump trucks, ecology, open-pit mining, emissions, diesel fuel, trolley truck, energy saving, dumper.

\section{Ключевые слова:}

карьерные самосвалы, экология,

открытые горные работы,

выбросы, дизельное топливо,

троллейвоз, энергосбережение, самосвал.

\begin{abstract}
Open-cut mining is the main way to extract minerals. Up to $80 \%$ of the rock mass produced by that is transported by dump trucks with diesel engines. Atmospheric gas pollution is an essential disadvantage of using diesel vehicles, especially in deep formations. Exhaust gases from diesel vehicles have a detrimental effect on human health and the environment. Constant exposure of exhaust gases on the body can cause immune deficiency, bronchitis, cerebral vessels and nervous system suffer. The higher the depth of mining the higher the concentration of machinery on formations and the worse the conditions of natural ventilation of the working space. At the depth of quarries over 200-250 m air pollution by harmful substances at the workplace leads to a gradual increase of the maximum permissible concentrations. That affects both people and economy of the enterprise since it entails the necessity to shut the career down, deteriorate visibility on the highway, which also causes a partial or total suspension of equipment operation. Transfer of dump trucks to electricity is a prospect way to solve the problem. Together, all the positive qualities of trolley trucks reduce the maintenance costs of transportation of rock mass by $15-20 \%$, as well as exclude the gassing of the quarry and formation of smoke. Need for power from the contact network is the most serious drawback of trolley truck. Today, thanks to modern technologies, eliminating most of the drawbacks of trolley trucks is not difficult. Quarry trolley trucks are better used only for long-term development, since the content of the trolley line contact requires attendance and maintenance. The payback period can be 2-4 years.
\end{abstract}

Основным способом добычи полезных ископаемых являются открытые горные работы. До 80 \% горной массы, получаемой при этом, перевозится карьерными самосвалами с дизельными двигателями. Существенным недостатком использования дизельного автотранспорта является загазованность атмосферы, особенно на глубоких горизонтах. Выхлопные газы дизельного автотранспорта оказывают вредное влияние на здоровье человека и окружающую среду. При постоянном воздействии выхлопных газов на организм могут развиваться иммунодефицит, бронхиты, страдают сосуды головного мозга, нервная система. С ростом глубины горных работ возрастает концентрация техники на горизонтах, ухудшаются условия естественного проветривания рабочего пространства карьеров. На глубине карьеров более 200-250 м загрязнение воздуха вредными веществами на рабочих местах приводит к постепенному превышению предельно допустимых концентраций. Это сказывается не только на людях, но и на экономике предприятия, так как влечет за собой необходимость остановки карьера, ухудшение видимости на трассе, что также обусловливает частично или полностью приостановку работы оборудования. Перспективным направлением решения проблемы является перевод карьерных самосвалов на электроэнергию. В совокупности все положительные качества троллейвоза понижают эксплуатационные расходы на транспортирование горной массы на 15-20\%, а также исключают загазованность карьера и образование дыма. Самым серьёзным недостатком троллейвоза является необходимость в питании от контактной сети. В настоящее время, благодаря современным технологиям, устранение большинства недостатков троллейвоза не представляет сложности. Карьерные троллейвозы лучше использовать только на долгосрочных разработках, поскольку содержание контактной сети троллейных линий требует ухода и обслуживания. Срок окупаемости затрат может составить 2-4 года.

Mark L. Khazin - Doctor of Engineering, Professor (tel.: +007 912269 81 72, e-mail: Khasin@ursmu.ru). The contact person for correspondence. Aleksandr P. Tarasov - Engineer (tel.: +007 90287281 17, e-mail: tp6005@mail.ru).

Хазин Марк Леонтьевич - доктор технических наук, профессор (тел.: +007 91226981 72, e-mail: Khasin@ursmu.ru). Контактное лицо для переписки. Тарасов Александр Петрович - инженер (тел.: +007 90287281 17, e-mail: tp6005@mail.ru). 


\section{Introduction}

A typical feature of the present period of time is that more deep fields are being developed and their geological conditions become more worse. Transportation is the most complex, laborconsuming and costly link in development of mineral deposits by the open method. That's share in production costs is $60-75 \%$, especiallyin deep quarries [1]. Automobile transportation is the main type of technological transportation when extracting minerals by the open method. That is used to transport approximately $80 \%$ of the entire rock mass. At the same time, the world mining industry annually consumes billions of liters of diesel fuel, with $70-80 \%$ of the total volume of fuel consumed by loaded dumpers on uphills.

\section{The impact of diesel engine emissions on human health and the environment}

According to Parker Bay, the number of dumpers in use in the world for 2014 increased from 38.5 to 43.0 thousand units. In 2012, 1725 quarry dumpers operated in Russia's quarries. Only BelAZ annually sells about 800 dumpers in Russia, and this number increases constantly. In JanuaryFebruary 2018, 40 units of quarry dumpers were delivered to the Russian market more than last year for the same period [2].

All modern automobiles used in quarries are equipped with diesel engines with capacity of $150-2600 \mathrm{~kW}$ with a turbocharging and working volume of 10 to $117 \quad$ [3]. There are certain shortcomings along with numerous advantages of road transport. One of the significant shortcomings of the use of diesel vehicles of the modern type is the release of a significant amount of exhaust gas, which leads to atmosphere pollution by gases, especially in deep formations.

Exhaust gases represent an inhomogeneous mixture of various gaseous substances with diverse chemical and physical properties, consisting of products of complete and incomplete combustion of fuel, excess air, aerosols and various microimpurities (both gaseous and liquid and solid particles) coming from cylinder engines into its exhaust system. They are composed of about
300 substances, most of which are toxic, which negatively affects human health and the environment. Carbon, nitrogen and hydrocarbon oxides are the main regulated toxic components of engine exhaust. In addition, with exhaust gases, limiting and unsaturated hydrocarbons, aldehydes, carcinogens, soot and other components enter the atmosphere (Table 1).

Table 1

Exemplary composition of exhaust gases of a diesel engine

\begin{tabular}{|l|c|c|}
\hline Component of exhaust gas & Content by volume, $\%$ & Toxicity \\
\hline Nitrogen & $76.0-78.0$ & No \\
\hline Oxygen & $2.0-18.0$ & No \\
\hline Water vapor & $0.5-4.0$ & No \\
\hline Carbon dioxide & $1.0-10.0$ & No \\
\hline Carbon monoxide & $0.01-0.2$ & Yes \\
\hline $\begin{array}{l}\text { Hydrocarbons } \\
\text { are non-carcinogenic }\end{array}$ & $0.009-0.5$ & Yes \\
\hline Aldehydes & $0.001-0.009$ & Yes \\
\hline Sulfur oxide & $0-0.03$ & Yes \\
\hline Soot, $\mathrm{g} / \mathrm{m}^{3}$ & $0.01-1.1$ & Yes \\
\hline Benzpyren, $\mathrm{mg} / \mathrm{m}^{3}$ & up to 0.01 & Yes \\
\hline
\end{tabular}

Nitric oxides cause headache, loss of consciousness and irritation of the respiratory tract as well.

Sulfur dioxide is a corrosive gas causes acute irritation of eyes, nose and throat.

Hydrocarbons $\left(\mathrm{C}_{\mathrm{n}} \mathrm{H}_{\mathrm{m}}\right.$ - ethane, methane, ethylene, benzene etc.) are toxic substances. The content of $\mathrm{C}_{\mathrm{n}} \mathrm{H}_{\mathrm{m}}$ in an exhaust gas increases with throttling, when the engine is running in the forced idling mode, for example, when braking. They play an active role in formation of biologically active substances that irritate the eyes, throat, nose and their disease and damage the plant and animal life. Hydrocarbon compounds have a narcotic effect on the central nervous system, can cause chronic diseases. Hydrocarbons (olefins) and nitrogen oxides under certain meteorological conditions actively contribute to smog formation.

Diesel particles (Particulate Matter, PM) are a complex set of solid and liquid materials that agglomerate carcinogens - polycyclic aromatic hydrocarbons. Particles have a very complex composition and can contain up to $43 \%$ soot, up 
to $5 \%$ insoluble oil fractions, up to $10 \%$ soluble fuel fractions and up to $13 \%$ sulfates and water vapor $[4,5]$.

The greatest danger is represented by nanoparticles with a diameter of less than $50 \mathrm{~nm}$ which deeply penetrate into the human lungs and promote development of cardiovascular and cancer diseases. Moreover, new more modern models of diesel engines produce more fine particles than diesel engines manufactured using the old technology [5].

In addition, diesel engines emmits more smoke. The smokiness of diesel engines, or smog from exhaust gases, is a toxic fog formed in the lower atmosphere, contaminated with exhaust fumes from vehicles under adverse weather conditions. That is an aerosol consisting of smoke, fog, dust, particles of soot, and droplets of liquid (in a humid atmosphere). That occurs in the atmosphere under certain meteorological conditions. Harmful gases entering the atmosphere react with each other and form new, including toxic compounds. As a result of complex photochemical processes in the atmosphere, stimulated by ultraviolet solar radiation, photoxidants (oxidants) are formed from oxides of nitrogen, hydrocarbons, aldehydes and other substances. Low concentrations of $\mathrm{NO}_{2}$ can create a large amount of atomic oxygen, which in turn forms ozone and reacts again with substances that pollute the atmospheric air. Formaldehyde, higher aldehydes and other hydrocarbon compounds presented in the atmosphere, as ozone, contribute to formation of new peroxide compounds. Dissociation products react with olefins, forming toxic nitroperoxy compounds. If their concentration is more than $0.2 \mathrm{mg} / \mathrm{m}^{3}$ there is condensation of water vapor in the form of the smallest droplets of fog with toxic properties. Their number depends on the season of the year, time of day and other factors. If the weather is hot and dry that is observed in the form of a yellow veil (color is given by $\mathrm{NO}_{2}$, a droplet of yellow liquid present in the air). Smog causes irritation of mucous membranes, especially the eye, can cause headache, swelling, hemorrhage, complications of respiratory diseases. It worsens visibility on roads, thereby increasing the number of road accidents.

With constant exposure to exhaust gases, the body can develop immunodeficiency, bronchitis, brain vessels, nervous system and other organs. Formaldehydes and other hydrocarbons in the exhaust gases of diesel engines may cause cancer in humans when exposed during the year. Lung cancer was also detected in miners who were exposed to the exhaust gases of diesel engines for 10-20 years $[4,6]$.

In June 2012, the World Health Organization (WHO) classified emissions from diesel engines as carcinogenic. According to WHO findings, the impact of PM2.5 reduces the life expectancy of people by an average of 8.6 months $[6,7]$.

When the depth of mining operations is high the amount of equipment in formations increases, the conditions for natural ventilation of the working space of quarries deteriorate. Air pollution by harmful substances in workplaces at the depth of quarries more than 200-250 m leads to a gradual excess of the maximum permissible concentrations: $3-5$ times by dustiness of air in workplaces, in 1.5-3.0 times for carbon oxides, in 5-7 times for nitrogen oxides [8-11] - and does not meet the requirements of GOST 12.1.005-88 "Air working area". That emerge occupational diseases, decrease labor productivity and industrial injuries.

\section{The impact of diesel engine emissions on the economy of an enterprise}

An increase in standards affects both human factor and economy of an enterprise, since it entails the need to stop the quarry, the deterioration of visibility on the track, which also causes partial or complete suspension of the equipment.

Under adverse weather conditions (AWC combination of calm and inversions), the environmental situation only worsens, but in accordance with the requirements of uniform safety rules there is a need to stop mining operations only. Duration of AWC for quarries in Yakutia, Eastern Siberia, north-west and the Urals is $3500,2720,1650$ and 1220 hours per year, respectively. 
For example, according to Alrosa, the "Udachny" quarry due to gas pollution in 1988 stood for 145 hours, in $1989-1108$, in $1990-$ 1529 , in $1991-1894$, in $1992-2340$, in $1993-$ 1958, in 1994 - 1985, in 1995 - 2116, in $1996-$ 1286, in 1997 - 1479, in 1998 - 1302 hours (with the average height of the of rock mass lifting of $200-450 \mathrm{~m}$ ).

This problem is especially urgent for the Yubileiny mine (AK Alrosa), whose depth in 1999 reached $110 \mathrm{~m}$. Possibilities of natural air ventillation are very limited due to low average annual wind speed $(3.5 \mathrm{~m} / \mathrm{s})$ and considerable duration calm period $(11 \%)$. Downtime of quarries due to gas contamination sometimes reaches 1500 hours per year. An increase in quarry depth of 300-500 $\mathrm{m}$ increases the length of the route along the serpentine to $5 \mathrm{~km}$, which further exacerbates the problem of gas contamination and increases idleness. At the same time huge energy resources are being spent on lifting ore by dump trucks, since the power of diesel generators of dump trucks reaches $2000 \mathrm{~kW}$ and more. All this causes a loss of productivity and, as a result, economic damage [11].

Study of working conditions for drivers of quarry dump trucks at the Navoi Mining and Metallurgical Combine, ore mining plants "Aikhalsky", "Yubileiny", "Udachny", and "Kovdor" has shown that it is necessary to reduce emissions of exhaust gases when the engines are idling and at low loads [11-13].

Therefore, even in spite of the use of local and individual means of protection for operators of machinery operating in a quarry, the process often stops precisely because of lack of visibility and inability to safely conduct work in a quarry. As a consequence, issues of the ecology of the atmosphere of quarries are the most important.

\section{Ways to reduce the environmental pressure}

Reducing the environmental pressure on the environment is extremely important in development of mineral deposits. Increasing environmental standards in many countries require a radical reduction in volume and toxicity of exhaust emissions. Emission reduction is also important for municipalities adjacent to enterprises, because emissions of diesel equipment, including soot particles, or so-called "black carbon" (Black Carbon, VS), have a negative impact on public health. Using more "clean" engines, companies avoid significant environmental payments, in addition, real working conditions in quarries are substantially improved, visibility is improved, risks and the number of accidents are reduced [14].

In October 2014 the European Commission adopted the "Directive on Fuel Quality", requiring distributors of fuel for road transport to reduce the intensity of exhaust emissions by $6 \% 2020$ [15].

First of all, when you solve the problems of normalizing the ecological situation in quarries, you need to know how many harmful substances are released into the atmosphere when dumper operate. According to stidues [11, 16, 17], the number of dumpers depends on many factors: specific fuel consumption per unit of transport work, operating mode of a diesel engine, loadcarrying capacity of dumpers, time of year etc. The statistics of specific emissions of harmful substances is given for example of BelAZ automobile (Table 2).

Normalization of the atmosphere in quarries with automobile transport can be achieved in several ways:

- ventilation with air by natural (mainly on uphill quarries) and artificial with the help of stationary and mobile fan units;

- operation of low-toxic diesel engines;

- development of new, environmentally cleaner engine designs;

- reduction of fuel consumption for transportation of rock mass;

- use of special additives to fuel, reducing emissions of soot in the atmosphere;

- use of waste gas neutralizers installed on automobiles directly behind the diesel engine;

- use of alternative fuels and energy.

Extensive research conducted in the direction of normalization of the atmosphere of open pits [19-22], showed that the costs of ventilating quarries are significant, require to create technically complex and costly ventilating plants, 
Table 2

Specific emissions of harmful substances by a diesel engine of the BelAZ automobile [18]

\begin{tabular}{|c|c|c|c|c|c|c|c|}
\hline \multirow[t]{2}{*}{ Dumper } & \multirow[t]{2}{*}{ Tonnage, $\mathrm{t}$} & \multirow[t]{2}{*}{ Engine } & \multirow{2}{*}{$\begin{array}{c}\text { Engine } \\
\text { power, } \mathrm{kW}\end{array}$} & \multirow[t]{2}{*}{ Component } & \multicolumn{3}{|c|}{$\begin{array}{l}\text { Specific emissions of harmful substances } \\
\text { by diesel engines of automobiles, } \mathrm{g} / \mathrm{h}\end{array}$} \\
\hline & & & & & idling & $50 \%$ of power & maximum power \\
\hline \multirow{5}{*}{ BelAZ 75213} & \multirow{5}{*}{170} & \multirow{5}{*}{$\begin{array}{c}\text { YaMZ } \\
240 \mathrm{PM} 2\end{array}$} & \multirow{5}{*}{1691} & $\mathrm{CO}$ & 874 & 1413 & 1961 \\
\hline & & & & $\mathrm{NO}_{x}$ & 642 & 4706 & 8605 \\
\hline & & & & $\mathrm{CH}$ & 214 & 427 & 804 \\
\hline & & & & $\mathrm{C}$ & 69 & 139 & 255 \\
\hline & & & & Benzpyren & 0.001 & 0.001 & 0.002 \\
\hline \multirow{5}{*}{ BelAZ 7519} & \multirow{5}{*}{110} & \multirow{5}{*}{$8 \mathrm{DM}-21 \mathrm{~A}$} & \multirow{5}{*}{956} & $\mathrm{CO}$ & 494 & 1081 & 1108 \\
\hline & & & & $\mathrm{NO}_{x}$ & 363 & 2660 & 4876 \\
\hline & & & & $\mathrm{CH}$ & 121 & 242 & 443 \\
\hline & & & & $\mathrm{C}$ & 23 & 79 & 144 \\
\hline & & & & Benzpyren & 0.002 & 0.002 & 0.002 \\
\hline \multirow{5}{*}{ BelAZ 7549} & \multirow{5}{*}{80} & \multirow{5}{*}{ 6DM21A } & \multirow{5}{*}{772} & $\mathrm{CO}$ & 370 & 488 & 895 \\
\hline & & & & $\mathrm{NO}_{x}$ & 254 & 2148 & 3938 \\
\hline & & & & $\mathrm{CH}$ & 98 & 195 & 358 \\
\hline & & & & $\mathrm{C}$ & 17 & 53 & 116 \\
\hline & & & & Benzpyren & 0.002 & 0.002 & 0.002 \\
\hline \multirow{5}{*}{$\begin{array}{l}\text { Diesel Trolley } \\
\text { Truck on the } \\
\text { basis of BelAZ } \\
7519\end{array}$} & \multirow{5}{*}{110} & \multirow{5}{*}{$6 \mathrm{DM}-21 \mathrm{~A}$} & \multirow{5}{*}{603} & $\mathrm{CO}$ & 350 & 834 & 1053 \\
\hline & & & & $\mathrm{NO}_{x}$ & 239 & 2280 & 3914 \\
\hline & & & & $\mathrm{CH}$ & 114 & 213 & 330 \\
\hline & & & & $\mathrm{C}$ & 13 & 60 & 104 \\
\hline & & & & Benzpyren & 0.002 & 0.002 & 0.002 \\
\hline
\end{tabular}

significant energy costs and usually economically unjustified. Costs of injecting clean air into a quarry necessary for airing often overlap the fuel consumption of mine dumpers even if the excavators in the bottom are powered from a cable-an AC or DC network.

In recent years, various studies have been carried out to improve the combustion process and fuel economy of diesel engines for quarry dumpers. An advanced temperature control system of the engine allows to reduce fuel consumption, pollutant emissions, warm-up time, and also to increase the overall performance of an engine. Nevertheless, up to $30 \%$ of the fuel is consumed by the energy scattered in the surrounding space [23].

Use of devices and systems for neutralization of exhaust gases, including neutralizers is the other way to reduce emissions of toxic substances. At the same time, it should be noted that quarry dumpers used in open pit mining are not equipped with neutralizers. In case neutralizers are installed on diesel engines, they effectively work only at temperature of exhaust gases above $300{ }^{\circ} \mathrm{C}$. In winter conditions, especially in northern regions, exhaust gases are rapidly cooled, which drastically reduces the degree of their purification [24]. The level of exhaust gas released by BelAZ dumpers in coal mines of Kuzbass (Kedrovskiy, Bachatskiy, Listvyanskiy, Olzherasskiy and Tomusinskiy) was studied. It is established [24] that reducing catalysts using rhodium have a low service life. If the fuel equipment and engine are faulty, the neutralizers fail after a few hours of operation. At the same time, the high temperature of the carrier unit leads to transition of $\mathrm{NO}_{x}$ to higher oxides, which means an even greater danger to humans and the environment when such gases are released into the atmosphere. In addition, neutralizers create increased resistance to the movement of exhaust gases and reduce engine power. So the driver often has to accelerate the diesel engine, thereby increasing the consumption of diesel fuel, and, therefore, release of hazardous substances into the atmosphere.

Development of fundamentally new fumeless types of engines and fuels is one of the main tasks of further development of automobile quarry 
transport that should be considered. Major modern developments are focused on improving the reliability of aggregates, implementation of more progressive power plants, including electric motors with frequency and pulse control, more economical and environmentally cleaner diesel engines.

Today, a large share of quarries is represented by imported dumpers, fuel equipment of which is equipped according to European standards. That allows them to have less negative impact on the region ecology. For example, the CAT-785C dumpers commissioned by JSC Lebedinskiy GOK in 2006 from the first months showed advantages in working before the BelAZ 7513 dumpers, which has almost the same lifting capacity. The cargo turnover exceeded the same indicator by $32 \%$, specific fuel consumption was lower by $25 \%$ under the same conditions. Reliability indicators, coefficient of technical readiness, durability and environmental characteristics are above those parameters. [25].

However, for the moment BelAZ dumpers are equipped with imported engines and, according to their environmental characteristics, in fact do not differ from foreign analogues [26] (Table 3).

An engine certified in accordance with the requirements of the newest environmental standard US EPA Tier 4 Final is the main feature of the new Caterpillar Cat $773 \mathrm{G}$ and Cat $775 \mathrm{G}$ quarry dump trucks, compared to the earlier models. Those are the first quarry dumpers with such high ecological characteristics. Both models are equipped with a technology of increasing the efficiency of combustion of fuel ACERT, neutralization system for nitrogen oxides, catalytic converter of exhaust gases and multistage filters are introduced. For Russia dumpers are equipped with a Tier 2 or EU Stage II engine. Each of them is equipped with a transmission control system (APES), which reduces fuel consumption in various driving modes [27].

Application of advanced diesel engines with low-toxic work processes, as well as expansion of the energy resource base as one of the ways to reduce the technogenic impact on the environment is a simple and effective solution to the problem of reducing emissions of toxic components in waste engine gases.

One of the options for increasing the efficiency and environmental friendliness of automobile transport in quarries is an application of dump trucks as part of career automoblie trains [28].

Field experience shows that one of the promising directions for solving the problem of expanding the energy resource base for vehicles is the use of gaseous fuels (natural, compressed, liquefied). Emissions of pollutants from engines using natural gas as a fuel for the most harmful components are 2-5 times less dangerous than for diesel engines. Application of the fuel made from natural gas allows reducing the smokiness of exhaust gases in almost 10 times, reducing specific emissions (per dump truck) in 2-3 times, $\mathrm{NO}_{x}-$ in 1.3-1.4 times, in solid particles - in 4-5 times. There is no soot formed inherent in diesel engines $[17,29-31]$.

Table 3

Environmental characteristics of quarry dumpers

\begin{tabular}{|c|c|c|c|c|c|c|c|}
\hline \multirow[t]{2}{*}{ Dumper } & \multirow[t]{2}{*}{ Tonnage, $\mathrm{t}$} & \multirow[t]{2}{*}{ Engine } & \multirow{2}{*}{$\begin{array}{c}\text { Engine } \\
\text { power, kW }\end{array}$} & \multicolumn{4}{|c|}{$\begin{array}{l}\text { Specific emissions of harmful substances by diesel } \\
\text { engines of automobiles, } \mathrm{g} / \mathrm{h}\end{array}$} \\
\hline & & & & $\mathrm{CO}$ & $\mathrm{NMHC}+\mathrm{NO}_{x}$ & $\mathrm{NO}_{x}$ & soot \\
\hline Howo ZZ5707S3840AJ & 50 & WD615.47T2 & 271 & 3.5 & 6.6 & - & 0.20 \\
\hline BelAZ-7555F & 55 & Cummins QSK 19-C & 522 & 3.5 & 6.4 & - & 0.20 \\
\hline BelAZ-7555E & 60 & Cummins QSK 19-C & 559 & 11.4 & 1.3 & 9.2 & 0.54 \\
\hline BelAZ-7555I & 60 & Liebherr D 9512 & 565 & 3.5 & 6.4 & - & 0.20 \\
\hline Komatsu HD785-5 & 91 & SA12V140 & 753 & 3.5 & 6.4 & - & 0.20 \\
\hline Caterpillar Cat 773G & 96.4 & Cat C27 ACERT & 547 & 3.5 & 6.4 & - & 0.20 \\
\hline Komatsu HD1500-7 & 141.1 & Komatsu SDA12V160 & 1048 & 11.4 & 7.4 & 9.2 & 0.50 \\
\hline Hitachi EH3500AC-3 & 181 & Cummins QSKTA50-CE & 1491 & 14.1 & 8.4 & 9.2 & 0.50 \\
\hline Liebherr T262 & 218 & Cummins QSK60 & 1492 & 14.1 & 8.4 & - & 0.50 \\
\hline
\end{tabular}


Application of engines of different fundamental solutions and types (gas turbine or electric motors with autonomous power supply from special sources) is the other promising direction.

\section{Trolley truck is the other eco-friendly quarry transport}

The share of air pollution is largely determined by the type of transport used (Fig. 1) and operation mode [32, 33].

Energy required for mining and processing of mineral ores is one of the biggest expense items in mining operations. This demand for energy is usually met by diesel fuel or electricity. Up to 70$80 \%$ of the total volume of fuel is consumed by loaded dump trucks on uphills. Taking into account the constantly increasing cost of diesel fuel (Fig. 2) used by quarry dump trucks, it can be predicted that in near future the share of fuel costs in the prime cost of transportation of rock mass will be increased in average in 1.5-2.0 times.

Ususally, the speed of the dump truck on a slope is limited by the power of a diesel engine. If the same dump truck can get more power, then it can support a higher speed. In this regard, the possibility of diesel-trolley and trolley transport should be noted $[1,9,10,32-35]$.

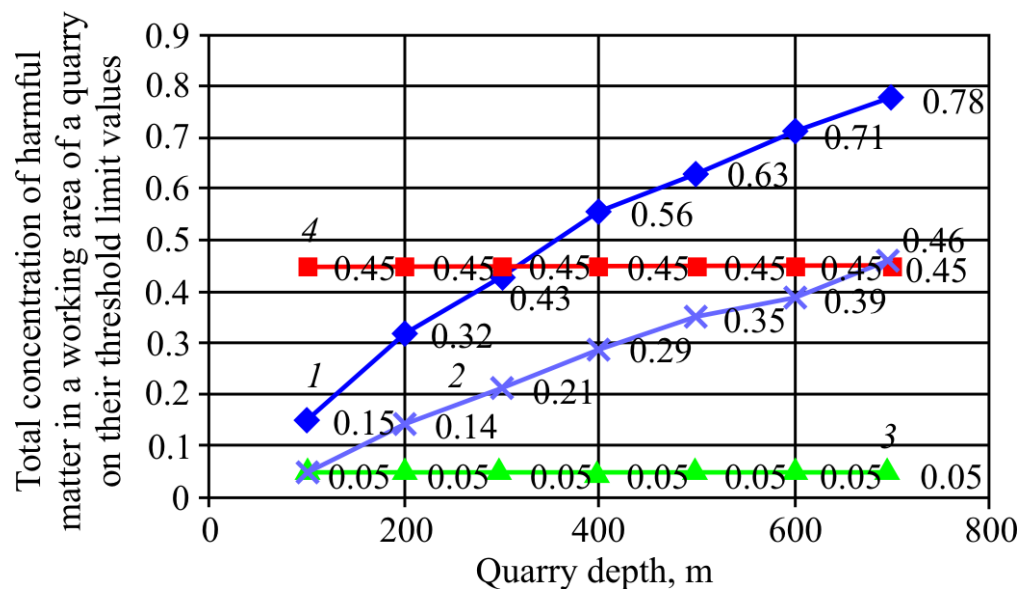

Fig. 1. Change in concentration of harmful matter in a working area of a quarry to their threshold limit values for various types of transport vehicles with a change in quarry depth [9]: 1 - diesel automobile transport; 2 - diesel-trolley transport; 3 - conveyor transport; 4 - threshold limit concentration

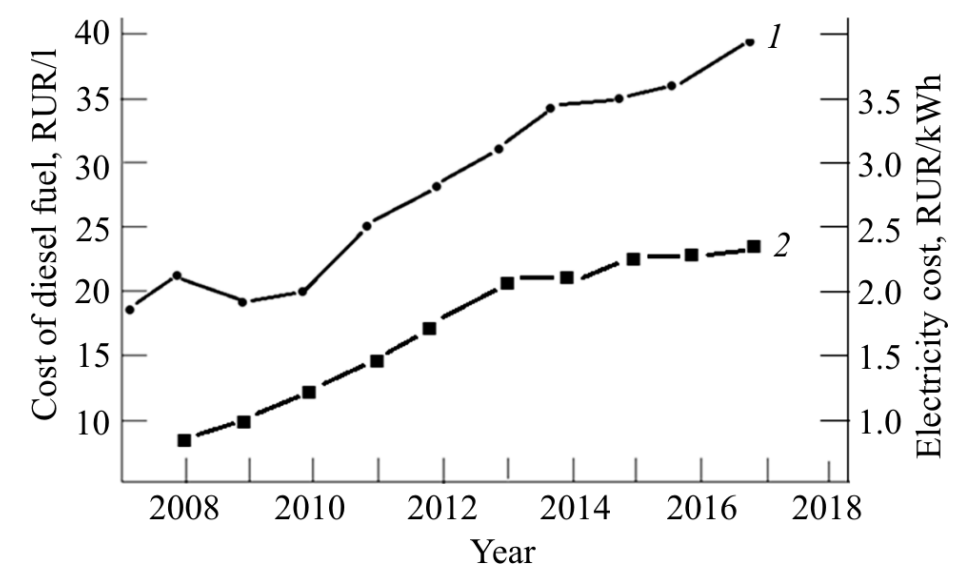

Fig. 2. Dynamics of the cost of diesel fuel (1) and electricity (2) in Russia (according to Rosstat) 
When using electric drives, the large power supplied to the wheeled engines allows the dump trucks to move faster on uphills, which leads to a reduction in the working cycle time and increase in production capacity during the extraction of minerals.

If the truck is used in a trolley mode, the engine is idling and fuel consumption is significantly reduced (Table 4), which reduces noise and emissions to the environment.

Table 4

Comparison of the Komatsu 730E dumper with a lifting capacity of 190 tonnes operating in different modes [36]

\begin{tabular}{|l|c|c|}
\hline \multicolumn{1}{|c|}{ Parameter } & $\begin{array}{c}\text { Diesel } \\
\text { mode }\end{array}$ & $\begin{array}{c}\text { Trolley } \\
\text { mode }\end{array}$ \\
\hline Speed, $\mathrm{km} / \mathrm{h}$ & 12.2 & 23.7 \\
\hline Fuel consumption, $1 / \mathrm{h}$ & 367 & 37.4 \\
\hline Electricity use, $\mathrm{kW}$ & 0 & 1930 \\
\hline The cost of fuel $(1.05 \mathrm{USD} / \mathrm{l})$ & 385.35 & 39.27 \\
\hline The cost of electricity $(0.07 \mathrm{USD} /(\mathrm{kw} / \mathrm{h}))$ & - & 135.10 \\
\hline Total cost $(\mathrm{USD} / \mathrm{h})$ & 385.35 & 174.37 \\
\hline
\end{tabular}

A significant progress has been made in production of electric dumpers over the past 20 years. Drive systems of dumpers consist of two electric motors, which are integrated via gears into the rear wheels of dumpers, electric generator and powerful diesel engine. Electricity can be obtained from an electric generator of a diesel engine on a dump truck or from a dedicated substation and through a pendant contact network directly to the engine of a mining dump truck.

Dumpers with electric drive equipped with current collectors can receive energy from the air contact network. Trolley systems, which replace diesel fuel for electricity, can offer another way for the further development of a career transport.

Currently, the total number of implemented trolley projects for quarry transport is relatively small and, unfortunately, most of them is abroad [1].

A transport system using diesel-trolley trucks has long been successfully operated in Africa, Brazil, the USA and Europe. There are 55 trolley trucks operating in a $2 \mathrm{~km}$ section
There are 55 trolley trucks operating in a $2 \mathrm{~km}$ section in Sishen (South Africa) quarries since January 1981. The Unit Rig Lectra Haul M200eT trolley truck serves $8 \mathrm{~km}$ was launched in Phalaborwa in October 1981. Since 1986 trolley trucks in mines and quarries have been used in Congo (Lubembashi quarry), Namibia (Rossing basin - Namib Desert), Gega copper mines near Lubumbashi in Zaire. The example of the Betze gold mine (the USA, Nevada), where a fleet of 73 diesel-trolley trucks with a carrying capacity of 170 tonnes is used for transportation of 410 thousand tonnes of rock per day, is particularly indicative.

Trolley trucks operate successfully on the Grootegeluk coal mines in South Africa [36] and Grivice in RMU Banovici in Bosnia and Herzegovina [37]. Quarry dump trucks-trolley trucks with carrying capacity of 254 tonnes of type Euclid-Hitachi EH4500 AC are used for coal transportation.

The trolley system can be installed at any part of the lift between the loading platform (quarry) and unloading points (a dump or process unit).

When extracting minerals following requirements similar to traction drives on light rail infrastructure have to be met: mechanical stability, reliability in operation and low operating costs. The infrastructure of the trolley-carrying complex includes a system of contact networks, traction substations, masts of high voltage lines, lighting of sagging system and current collector of a quarry dump truck [34-39]. Safety in operation and maintenance of electrified wheeled utility vehicles and railroad quarry vehicles is similar.

A possibility of recuperation into the network of kinetic energy released during braking, and potential energy when moving on a slope is the main energy advantage of a trolley truck in comparison with a dump truck having a traditional electromechanical transmission. In this case, one trolley line is used in the cargo direction. An energy accumulator is used for driving the trolley truck in the empty direction. That accumulates energy by recuperation of braking energy in the empty direction and can additionally be recharged from the trolley line. 
Recuperation of braking energy is one of the most promising sources of energy saving. A principal condition for implementation of energy recovery is the possibility of changing the direction of the energy flow between the supply network and traction engines. This can be achieved only with certain design features of the converter unit feeding the traction engines. The main advantages of reversible substations are [34-39]:

- recuperation of braking energy at any time while maintaining the priority of the natural energy exchange between dump trucks;

- DC output voltage regulation;

- reducing the level of harmonics and increasing the power factor on the AC side.

It was noted based on the analysis of operation of diesel-trolley trucks [34-39] that a loaded dump truck on a $1 \mathrm{~km}$ path, descending along a slope, recovers about $7900 \mathrm{kWh}$ of energy per day (work - 20 hours, 5 minutes of loading). If the energy cost is $\$ 0.077$ per $\mathrm{kWh}$ then the cost of energy recovery per day on a truck is $\$ 608$. When an empty dump truck moves in a similar profile, the cost of energy recovery for one dumper per day is $\$ 262$. The longer the uphill and larger the fleet size the greater savings will be.

At the same time, diesel-trolleys have inherent disadvantages:

- strong requirements for the construction and quality of the road surface;

- a need for additional costs to create and maintain a branched contact network;

- an increase in the cost of a diesel-trolley truck by $5-10 \%$ in comparison with standard dump trucks with an electric drive;

- an increase in mass of the diesel-trolley truck in comparison with diesel-electric dump truck due to the installation of trolley equipment.

Initially, the task of creating electrified transport was solved by installing an additional electric engine for a mining dump truck, i.e. the experimental samples were built on the basis of machines designed with use of a diesel engine as the power unit, for example BelAZ 75195 and other later models. Therefore, an electric engine was not able to demonstrate all the advantages over diesel one. Today, the automobile is designed based on selected electric power unit in order to take all the advantages of electric motor [40].

Trolley-truck (or trolley-battery dump truck) has additional advantages:

- much higher efficiency of the electric engine in comparison with diesel one;

- thermal energy loss is 3 times less than in a diesel engine of the same power;

- no diesel exhaust and, consequently, gas contamination of the quarry and formation of fog, i.e. significant improvement in the environmental situation;

- no spend for purchase, storage and transportation of diesel fuel;

- reduction of the cost of a dump truck with no diesel engine;

- reduction in tire costs due to the smaller mass of the trolley truck, especially in cases where trolley trucks are used almost on a horizontal road;

- easy to maintenance the power unit;

- no effect of frost on an electric engine, which is particularly advantageous from the diesel in the northern regions (strong negative temperatures have a negative effect mainly on batteries).

Long distances and steeper slopes provide an opportunity to approve all the advantages of a trolley truck in transportation of goods.

At the same time, the trolley automobile has shortcomings as common with diesel-trolley trucks, and their own [41]:

- engine supply from the air contact network;

- a need for additional spend to create and maintain a branched contact network;

- increased requirements for construction and quality of the road surface;

- low maneuverability;

- difficulty of loading and unloading processes.

The need for power from the contact network is the most serious shortcoming of the trolley. In order to ensure a trolley truck to work it is required to build a trolley track. Besides, since a quarry developes due to the mined mineral a route will need to be moved and supplemented by new sections sometimes. The route should be provided with the necessary number of traction substations 
and main power source of a network. A route should also be removed from the place of production of explosions at 300-600 m. In addition, high-voltage wires during the loading and unloading of the trolley truck are close enough and dangerous to touch.

In order to increase the maneuverability of a dumper an additional power unit such as diesel or gas-diesel can be applied. Installation of an additional power unit such as a diesel engine, can cause an increase in mass of an automobile, maintenance cost, emissions of fuel combustion products into the atmosphere. In case of a gasdiesel, a release of toxic fuel combustion products is much less.

Contact-battery dump trucks are the last resort, movement of which in deep part of quarries and at faces will be carried out with help of storage batteries and with help of a contact network when leaving the quarry. Batteries are insignificant increase the weight of the truck in comparison with internal combustion engines.

For example, the Chinese concern BYD Co. has developed a new dump truck BYD V60 with the wheel formula $6 \times 4$. Three-axle quarry dump truck with total weight of 60 tonnes and overall width of $3.2 \mathrm{~m}$ is designed for operation in coal mines, as well as poorly blown quarries. The tonnage of a machine is 30 tonnes only because of the huge curb weight of 30 tons, 10 tonnes of which loads the car battery and traction motors. The useful volume of the body is $30 \mathrm{~m}^{3}$. The Komatsu HD 605-7 dump truck (Fig. 3) is the best option with lifting capacity of 65 tonnes, electric motors of which are powered by accumulator batteries with a total capacity of $700 \mathrm{kWh}$, and weight of 4.5 tonnes. The dump truck is equipped with a regenerative braking system, which for a short trip can recharge the battery at $40 \mathrm{kWh}$. These electric dump trucks are working on a cement mine near the mountain Chasseral in Switzerland since the end of 2017.

The drawbacks of batteries are: short life of a small power reserve in comparison with an internal combustion engine and high cost of the battery cells themselves.

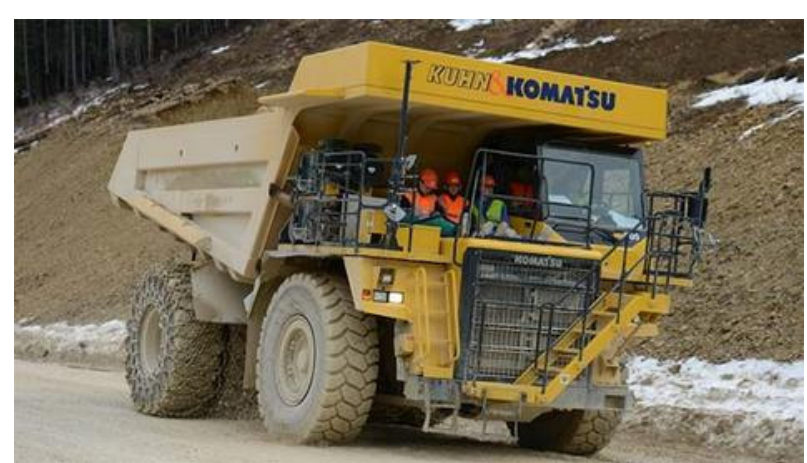

Fig. 3. Trolley truck (battery electric dumper) Komatsu HD 605-7

A possibility of using more power allows the trolley to move faster and overcome steep gradients (up to 100-120\%), which provides an increase in productivity.

An increase in effictiveness of the mining company can be achieved through significant fuel economy, increased productivity of the process of transporting rock mass, reducing the fleet, reducing operating and maintenance costs.

For example, if the duty cycle time is reduced by $20 \%$ as a result of the increase in speed on uphills, the fleet of 32 dump trucks is capable of delivering the same results as 40 diesel-powered dump trucks [36-39].

Costs of operating and maintaining the engine are directly related to the hours of operation of the dump trucks. Use of an electric motor powered from an overhead contact network while driving on an ascent reduces the operating time of the diesel engine, thereby increasing the overhauls. When moving down the hill the cost of consumed energy is reduced by regenerating and returning it to the grid.

Diesel-trolley trucks reduce the time of travel by $16 \%$, the fuel economy is $60-85 \%$ with each cycle up and down, the volume of harmful emissions in the atmosphere is reduced by 1.7-2.0 times, and only the dust content remains the same $[36-40,42]$.

A decisive role in assessing the effectiveness of diesel-trolley trucks is played by the ratio of prices for diesel fuel and electricity (see Fig. 2). Calculations, feasibility studies and practice show that the trolley system payd off for 2-4 years $[1,36-39,42]$. 
Analysis of experience of using diesel-trolley trucks in North America, Africa and Europe shows the prospects of this type of quarry transport. So, for example, BelAZ JSC plans to produce diesel-trolley trucks with the carrying capacity of 220-240 and 320-360 tonnes [40].

\section{Conclusion}

The ecological situation in quarries largely depends on the design perfection of transport vehicles, especially diesel engines. The increase in production also contributes to increased energy consumption and exhaust emissions. Due to the big amount and high toxicity exhaust gases of diesel engines exert extremely dangerous effects on human healthand the environment. Due to the fact that energy efficiency of enterprises increases, environmental requirements to reduce the toxicity of exhaust gases increase constantly there is a need to transfer quarry vehicles to other types of energy.

Diesel-trolley automobiles are faster than dumpers on horizontal sections and on uphills when powered by a contact network. When dieseltrolley trucks are used, fuel consumption is reduced by $50-60 \%$, the volume of harmful emissions to the atmosphere is reduced by $1.7-2.0$ times, vehicle productivity is increased by $40-50 \%$ and operating costs are reduced by $15-20 \%$ with diesel dump trucks. In addition, energy is recovered when the dump truck moves downhill.

Trolley trucks are beneficial for mining enterprises geographically located in areas with a big difference between the cost of diesel fuel and cost of electricity. Quarry trolley trucks are best used only on long-term developments, as the maintenance of the trolley line contact network requires care and maintenance.

\section{References}

1. Galkin V.I., Sheshko E.E. Problemy sovershenstvovaniia transportnykh sistem $\mathrm{v}$ gornoi promyshlennosti Rossii [Problems of improvement of transport systems in the mining industry of Russia]. Gornyi informatsionnoanaliticheskii biulleten (nauchno-tekhnicheskii zhurnal), 2011, no.1, pp.485-507.

2. "BelAZ" uvelichil eksport v Rossiiu na $65 \%$, available at: https://rg.ru/2018/03/05/belaz-uvelichileksport-v-rossiiu-na-65-procentov.html (accessed 12 March 2018).

3. Anistratov K.Iu. mirovye tendentsii razvitiia struktury parka karernoi tekhniki [World trends in the development of the park's career structure]. Gornaia promyshlennost, 2011, no.6, pp.22-26.

4. Taxell P., Santonen T. Diesel engine exhaust: basis for occupational exposure limit value. Toxicological Sciences, 2017, vol.158, no.2, pp.243-251. DOI: 10.1093/toxsci/kfx110.

5. Chernetsov D.A. Toksichnost otrabotavshikh gazov dizelei i ikh antropogennoe vozdeistvie [Toxicity of exhaust gases of diesel engines and their anthropogenic impact]. Voprosy sovremennoi nauki $i$ praktiki. Universitet im V.I. Vernadskogo, 2010, no.10-12, pp.54-59.

6. Thiruvengadam A., Besch M., Carder D., Oshinuga A. Unregulated greenhouse gas and ammonia emissions from current technology heavy-duty vehicles. Journal of the Air \& Waste Management Association, 2016, vol.66, no.11, pp.1045-1060. DOI: $10.1080 / 10962247.2016 .1158751$
7. Jacobs W., Hodkiewicz M.R., Bräunl T. A costbenefit analysis of electric loaders to reduce diesel emissions in underground hard rock mines. IEEE Transactions on industry applications, 2015, vol.51, no.3, pp.2565-2573. DOI: 10.1109/IAS.2014.6978456

8. Sheshko O.E. Ekologo-ekonomicheskoe obosnovanie vozmozhnosti snizheniia nagruzki na prirodnuiu sredu ot karernogo transporta [Ecological and economic substantiation of the possibility of reducing the load on the natural environment from quarry transport]. Gornyi informatsionno-analiticheskii biulleten, 2017, no.2, pp.241-252.

9. Sheshko O.E. Ekologo-ekonomicheskaia otsenka karernykh transportnykh mashin novogo pokoleniia [Ecological and economic assessment of new generation of career transport vehicles]. Nauchnyi vestnik moskovskogo gosudarstvennogo gornogo universiteta, 2013, no.12, pp.281-288.

10. Sheshko O.E. Ekologo-ekonomicheskoe sravnenie primeneniia $\mathrm{v}$ glubokikh karerakh dizel-trolleivozov $\mathrm{i}$ tsiklichno-potochnoi tekhnologii [Ecological-economic comparison of application in deep quarries of dieseltrolleybus and cyclic-flow technology]. Nauchnyi vestnik Moskovskogo gosudarstvennogo gornogo universiteta, 2013, no.5, pp.108-116.

11. Tarasov P.I., Zhuravlev A.G., Fefelov E.V. et al. Sokrashchenie zagazovannosti karernogo prostranstva pri primenenii novykh vidov karernogo transporta [Reduced gassing of the quarry space when applying new types of 
quarry transport]. Gornyi informatsionno-analiticheskii biulleten (nauchno-tekhnicheskii zhurnal), 2008, no.2, pp.260-271.

12. Kutenev V.F., Saikin A.M. Issledovanie vliianiia uslovii ekspluatatsii karernykh samosvalov na zagriaznenie vozdukha kabin voditelei [Investigation of the influence of the conditions of the operation of the quarry dump trucks on the air pollution of the booths of drivers]. Zhurnal avtomobilnykh inzhenerov, 2009, no.4 (57), pp.17-19.

13. Kuleshov A.N., Andreev L.N. Vliianie parametrov mikroklimata salonov gruzovykh avtomobilei na usloviia truda i metody ego uluchsheniia [Influence of parameters of microclimate of lorries' salons on working conditions and methods of its improvement]. Sovremennye tendentsii razvitiia nauki i tekhnologii, 2016, pp.68-72.

14. Kholod N.M., Malyshev V.S., Evans M. Snizhenie vybrosov chernogo ugleroda karernymi samosvalami [Reduction of black carbon emissions by dump trucks]. Gornaia promyshlennost, 2015, no.3 (121), pp.72-76.

15. Climate action: Reducing the carbon content of transport fuels, Press release, European Commission, Brussels, 2014, available at: http://europa.eu/rapid/pressrelease_IP-14-1095_en. htm (accessed 12 February 2018).

16. Soofastaei A., Aminossadat S.M., Kizil M.S. Payload variance plays a critical role in the fuel consumption of mining haul trucks. Aust Resour Invest., 2014, vol.8, no.4, pp.64-64.

17. Osorio-Tejada J., Llera E., Scarpellini S. LNG: an alternative fuel for road freight transport in Europe. WIT Transactions on The Built Environment, 2015, vol.168, pp.235-246. DOI: 10.2495/SD150211

18. Metodika rascheta vrednykh vybrosov sbrosov i otsenki ekologicheskogo ushcherba pri ekspluatatsii razlichnykh vidov karternogo transporta [Method of calculation of harmful emissions (discharges) and estimation of ecological damage at operation of various kinds of crank transport]. Moscow, Institut Gornogo dela imeni A.A. Skochinskogo, 1994, 52 p.

19. Morin A.S. Truboprovodnaia ventiliatsiia na karerakh [Pipeline ventilation in quarries]. Gornaia promyshlennost, 2002, no.3, pp.40-43.

20. Starostin I.I., Bondarenko A.V. Provetrivanie karerov struinymi ventiliatorami $\mathrm{V}$ komplekse $\mathrm{S}$ ustroistvom dlia aeratsii [Venting quarries with jet blowers in combination with aeration device]. Nauka $i$ obrazovanie: nauchnoe izdanie MGTU im. N.E. Baumana, 2015, no.1, pp.32-41.

21. Kozyrev S.A., Amosov P.V. Puti normalizatsii atmosfery glubokikh karerov [Ways of normalization of the atmosphere of deep quarries]. Vestnik Murmanskogo gosudarstvennogo tekhnicheskogo universiteta, 2014, vol.17, no.2, pp.231-237.
22. Xing Y., Song H., Yu M. et al. The characteristics of greenhouse gas emissions from heavy-duty trucks in the Beijing-Tianjin-Hebei (BTH) region in China. Atmosphere, 2016, vol.7, no.9, pp.121-132. DOI: $10.3390 /$ atmos 7090121

23. Nessim W., Zhang F.J, Zhao C.L. Optimizing operational performance of diesel mining truck using thermal management. Advanced Materials Research. Trans Tech Publications, 2013, vol.813, pp.273-277. DOI: 10.4028/www.scientific.net/AMR.813.273

24. Protasov S., Berezin A., Podgornyi A. et al. Khoroshii opyt luchshe pouchenii [Good experience is better than teaching]. Ugol Kuzbassa, 2017, no.4, pp.104-106.

25. Dronov N.N., Efremov I.U., Beklemishchev A.N. Opyt raboty karera Lebedinskogo GOKA: gigantskie masshtaby, originalnye tekhnologii, perspektivy razvitiia [Experience of Lebedinsky GOKA career career: gigantic scales, original technologies, prospects for development]. Gornyi zhurnal, 2009, no.11, pp.88-91.

26. Stepuk O.G., Semko S.N., Zuenok A.S. Bolshegruznye karernye samosvaly i mashiny povyshennoi prokhodimosti - seriinaia produktsiia predpriiatiia segodnia [The bulky dump trucks and highthroughput cars are serial products of the enterprise today]. Gornyi zhurnal, 2013, no.1, pp.30-41.

27. Popolnenie karernoi pleiady [Replenishment of a career galaxy]. Avtomobilnye dorogi, 2014, no.4(989), available at: http://www.avtodorogi-magazine.ru/item/194popolnenie-karernoj-pleyady. html (accessed 12 February 2018).

28. Tarasov P.I., Zyrianov I.V., Kondratiuk A.P., Khazin M.L. Avtopoezda - novaia tekhnika dlia effektivnogo osvoeniia kimberlitovykh mestorozhdenii Respubliki Sakha (Iakutiia) [Traction - a new technique for the effective development of kimberlite deposits of the Republic of Sakha (Yakutia)]. Gornaia promyshlennost, 2016, no.5. (129), pp.45-48.

29. Song H., Ou X., Yuan J. Wang C. Energy consumption and greenhouse gas emissions of diesel/LNG heavy-duty vehicle fleets in China based on a bottom-up model analysis. Energy, 2017, vol.140, pp.966-978. DOI: 10.1016/j.energy.2017.09.011.

30. Boichenko S.V., Shkilniuk I.A. Ekologicheskie aspekty ispolzovaniia motornykh topliv (obzor) [Environmental aspects of the use of motor fuels (review)]. Energotekhnologii i resursosberezhenie, 2014, no.5-6, pp.35-44.

31. Tarasov P.I., Khazin M.L., Furzikov V.V. Prirodnyi gaz - perspektivnoe motornoe toplivo karernogo avtotransporta dlia raionov Severa [Natural gas is a promising motor fuel for a quarry road vehicle for the North]. Gornaia promyshlennost, 2016, no.6, pp.51-61. 
32. Tarasov P.I., Tarasov A.P. Tekhnologicheskie osobennosti i perspektivy primeneniia trolleivozov na gornykh predpriiatiiakh [Technological features and prospects of the use of trolls in mining enterprises]. Gornaia promyshlennost, 2008, no.1, pp.54-62.

33. Feng Y., Dong Z., Yang J. Performance modeling and cost-benefit analysis of hybrid electric mining trucks. Mechatronic and Embedded Systems and Applications (MESA). 12th IEEE/ASME International Conference on, 2016, pp.1-6. DOI: 10.1109/MESA.2016.7587102

34. Lajunen A. Energy efficiency of conventional, hybrid electric, and fuel cell hybrid powertrains in heavy machinery. SAE Technical Paper, 2015. DOI: 10.4271/2015-01-2829.

35. Esfahanian E., Meech J. A. Hybrid electric haulage trucks for open pit mining. IFAC Proceedings Volumes, 2013, vol.46, no.16, pp.104-109. DOI: 10.3182/20130825-4-US-2038.00042

36. Mazumdar J. All electric operation of ultraclass mining haul trucks. Industry Applications Society Annual Meeting, IEEE, 2013, pp.1-5. DOI: 10.1109/IAS.2013.6682568

37. Nurić S., Nurić A., Brčaninović M. Haulage solutions with trolley assist diesel-electric ac trucks on the pit mine RMU Banovici. Journal of Mining and Metallurgy A: Mining, 2009, vol.45, no.1, pp.78-87.

38. Varaschin J., De Souza E. Economics of diesel fleet replacement by electric mining equipment. 15th North American Mine Ventilation Symposium, 2015, 8 p.

39. Uno K., Imaie K., Maekawa K., Smith G., Suyama A., Hatori J. Development of mining machinery and future outlook for electrification. Hitachi Review, 2013, vol.62, no.2, pp.100-112.

40. Stepuk O.G., Zuenok A.S. Dizel-trolleivoznyi transport BelAZ: perspektivy ispolzovaniia $\mathrm{V}$ gornom proizvodstve [Diesel-trolleybus transport BelAZ: prospects of use in mining]. Gornyi zhurnal, 2013, no.1, pp.52-55.

41. Khazin M.L., Shtykov S.O. Prichiny zatrudniaiushchie primenenie trolleivozov $\mathrm{V}$ gornoi promyshlennosti [Reasons for the use of trolls in the mining industry]. Tekhnologicheskoe oborudovanie dlia gornoi $i$ neftegazovoi promyshlennosti, 2017, pp.380-382.

42. Cruzat J.V., Valenzuela M.A. Modeling and evaluation of benefits of trolley assist system for mining trucks. Industry Applications Society Annual Meeting, IEEE, 2017, pp.1-10. DOI: 10.1109/IAS.2017.8101840

\section{Библиографический список}

1. Галкин В.И., Шешко Е.Е. Проблемы совершенствования транспортных систем в горной промышленности России // Горный информационноаналитический бюллетень (научно-технический журнал). - 2011. - № 1. - С. 485-507.

2. «БелАЗ» увеличил экспорт в Россию на $65 \%$ [Электронный ресурс]. - URL: https://rg.ru/2018/03/05/ belaz-uvelichil-eksport-v-rossiiu-na-65-procentov.html (дата обращения: 12.03.2018).

3. Анистратов К.Ю. Мировые тенденции развития структуры парка карьерной техники // Горная промышленность. - 2011. - № 6. - С. 22-26.

4. Taxell P., Santonen T. Diesel engine exhaust: basis for occupational exposure limit value // Toxicological Sciences. - 2017. - Vol. 158, № 2. - P. 243-251. DOI: 10.1093/toxsci/kfx110.

5. Чернецов Д.А. Токсичность отработавших газов дизелей и их антропогенное воздействие // Вопросы современной науки и практики. Университет им. В.И. Вернадского. - 2010. - № 10-12. - С. 54-59.

6. Greenhouse gas and ammonia emissions from current technology heavy-duty vehicles / A. Thiruvengadam, M. Besch, D. Carder, A. Oshinuga // Journal of the Air \& Waste Management Association. 2016. - Vol. 66, № 11. - P. 1045-1060. DOI: $10.1080 / 10962247.2016 .1158751$
7. Jacobs W., Hodkiewicz M.R., Bräunl T. A Costbenefit analysis of electric loaders to reduce diesel emissions in underground hard rock mines // IEEE Transactions on industry applications. - 2015. - Vol.51, № 3. - P. 2565-2573. DOI: 10.1109/IAS.2014.6978456

8. Шешко О.Е. Эколого-экономическое обоснование возможности снижения нагрузки на природную среду от карьерного транспорта // Горный информационно-аналитический бюллетень. - 2017. № 2. - С. 241-252.

9. Шешко О.Е. Эколого-экономическая оценка карьерных транспортных машин нового поколения // Научный вестник Московского государственного горного университета. - 2013. - № 12 . C. 281-288.

10. Шешко О.Е. Эколого-экономическое сравнение применения в глубоких карьерах дизель-троллейвозов и циклично-поточной технологии // Научный вестник Московского государственного горного университета. 2013. - № 5. - С. 108-116.

11. Сокращение загазованности карьерного пространства при применении новых видов карьерного транспорта / П.И. Тарасов, А.Г. Журавлев, Е.В. Фефелов [и др.] // Горный информационноаналитический бюллетень (научно-технический журнал). - 2008. - №. 2. - С. 260-271. 
12. Кутенев В.Ф., Сайкин А.М. Исследование влияния условий эксплуатации карьерных самосвалов на загрязнение воздуха кабин водителей // Журнал автомобильных инженеров. - 2009. - № 4 (57). C. $17-19$.

13. Кулешов А.Н., Андреев Л.Н. Влияние параметров микроклимата салонов грузовых автомобилей на условия труда и методы его улучшения // Современные тенденции развития науки и технологий. 2016. - C. $68-72$.

14. Холод Н.M., Малышев В.С., Эванс М. Снижение выбросов черного углерода карьерными самосвалами // Горная промышленность. - 2015. - № 3 (121). - C. 72-76.

15. Climate action: Reducing the carbon content of transport fuels, Press release / European Commission, Brussels, 2014 [Электронный pecypc]. - URL: http://europa.eu/rapid/press-release_IP-14-1095_en.htm (дата обращения: 12.02.2018).

16. Soofastaei A., Aminossadat S.M., Kizil M.S., Payload variance plays a critical role in the fuel consumption of mining haul trucks // Aust Resour Invest. 2014. - Vol. 8, № 4. - P. 64-64.

17. Osorio-Tejada J., Llera E., Scarpellini S. LNG: an alternative fuel for road freight transport in Europe // WIT Transactions on The Built Environment. - 2015. - Vol. 168. - P. 235-246. DOI: $10.2495 /$ SD150211

18. Методика расчета вредных выбросов (сбросов) и оценки экологического ущерба при эксплуатации различных видов картерного транспорта. - М.: Ин-т горн. дела им. А.А. Скочинского, 1994. - 52 с.

19. Морин А.С. Трубопроводная вентиляция на карьерах // Горная промышленность. - 2002. - № 3. C. $40-43$.

20. Старостин И.И., Бондаренко А.В. Проветривание карьеров струйными вентиляторами в комплексе с устройством для аэрации // Наука и образование: научное издание МГТУ им. Н.Э. Баумана. - 2015. № 1. - С. 32-41.

21. Козырев С.А., Амосов П.В. Пути нормализации атмосферы глубоких карьеров // Вестник Мурманского государственного технического университета. 2014. - T. 17, № 2. - C. 231-237.

22. The characteristics of greenhouse gas emissions from heavy-duty trucks in the Beijing-Tianjin-Hebei (BTH) region in China / Y. Xing, H. Song, M. Yu [et al.] // Atmosphere. - 2016. - Vol. 7, № 9. - P. 121-132. DOI: $10.3390 /$ atmos 7090121

23. Nessim W., Zhang F.J., Zhao C.L. Optimizing operational performance of diesel mining truck using thermal management // Advanced Materials Research. -
Trans Tech Publications. - 2013. - Vol. 813. - P. 273277. DOI: 10.4028/www.scientific.net/AMR.813.273

24. Хороший опыт лучше поучений / С. Протасов, А. Березин, А. Подгорный [и др.] // Уголь Кузбасса. 2017. - № 4. - С. 104-106.

25. Дронов Н.Н., Ефремов Ю.И., Беклемищев А.Н. Опыт работы карьера Лебединского ГОКА: гигантские масштабы, оригинальные технологии, перспективы развития // Горный журнал. - 2009. № 11. - С. 88-91.

26. Степук О.Г., Семко С.Н., Зуёнок А.С. Большегрузные карьерные самосвалы и машины повышенной проходимости - серийная продукция предприятия сегодня // Горный журнал. - 2013. № $1 .-$ С. $30-41$.

27. Пополнение карьерной плеяды [Электронный ресурс] // Автомобильные дороги. - 2014. - № 4(989). URL: $\quad$ http://www.avtodorogi-magazine.ru/item/194popolnenie-karernoj-pleyady. html (дата обращения: 12.02.2018).

28. Автопоезда - новая техника для эффективного освоения кимберлитовых месторождений Республики Саха (Якутия) / П.И. Тарасов, И.В. Зырянов, А.П. Кондратюк, М.Л. Хазин // Горная промышленность. 2016. - № 5 (129). - С. 45-48.

29. Energy consumption and greenhouse gas emissions of diesel/LNG heavy-duty vehicle fleets in China based on a bottom-up model analysis / H. Song, X. Ou, J. Yuan, C. Wang // Energy. - 2017. - Vol. 140. P. 966-978. DOI: 10.1016/j.energy.2017.09.011

30. Бойченко С.В., Шкильнюк И.А. Экологические аспекты использования моторных топлив (обзор) // Энерготехнологии и ресурсосбережение. - 2014. № 5-6. - C. 35-44.

31. Тарасов П.И., Хазин М.Л., Фурзиков В.В. Природный газ - перспективное моторное топливо карьерного автотранспорта для районов Севера // Горная промышленность. - 2016. № 6. - C. 51-61.

32. Тарасов П.И., Тарасов А.П. Технологические особенности и перспективы применения троллейвозов на горных предприятиях // Горная промышленность. 2008. - № 1. - C. 54-62.

33. Feng Y., Dong Z., Yang J. Performance modeling and cost-benefit analysis of hybrid electric mining trucks // Mechatronic and Embedded Systems and Applications (MESA): 12th IEEE/ASME International Conference on. - 2016. - P. 1-6. DOI: 10.1109/MESA.2016.7587102

34. Lajunen A. Energy efficiency of conventional, hybrid electric, and fuel cell hybrid powertrains in heavy machinery. - SAE Technical Paper, 2015. - DOI: $10.4271 / 2015-01-2829$ 
35. Esfahanian E., Meech J.A. Hybrid electric haulage trucks for open pit mining // IFAC Proceedings Volumes. 2013. - Vol. 46, № 16. - P. 104-109. DOI: 10.3182/20130825-4-US-2038.00042

36. Mazumdar J. All electric operation of ultraclass mining haul trucks // Industry Applications Society Annual Meeting, 2013 IEEE. 2013. P. 1-5. DOI: 10.1109/IAS.2013.6682568.

37. Nurić S., Nurić A., Brčaninović M. Haulage solutions with trolley assist diesel-electric ac trucks on the pit mine RMU Banovici // Journal of Mining and Metallurgy A: Mining. - 2009. - Vol. 45, № 1. P. 78-87.

38. Varaschin J., De Souza E. Economics of diesel fleet replacement by electric mining equipment // 15th North American Mine Ventilation Symposium. 2015. -8 p.
39. Development of mining machinery and future outlook for electrification / K. Uno, K. Imaie, K. Maekawa, G. Smith, A. Suyama, J. Hatori // Hitachi Review. - 2013. - Vol. 62, №. 2. - P. 100-112.

40. Степук О.Г., Зуёнок А.С. Дизель-троллейвозный транспорт БелАЗ: перспективы использования в горном производстве // Горный журнал. - 2013. № 1. - С. 52-55.

41. Хазин М.Л., Штыков С.О. Причины, затрудняющие применение троллейвозов в горной промышленности // Технологическое оборудование для горной и нефтегазовой промышленности. - 2017. C. 380-382.

42. Cruzat J.V., Valenzuela M.A. Modeling and evaluation of benefits of trolley assist system for mining trucks // Industry Applications Society Annual Meeting, 2017 IEEE. - 2017. - P. 1-10. DOI: 10.1109/IAS.2017.8101840

Please cite this article in English as:

Khazin M.L., Tarasov A.P. Ecological and economic evaluation of quarry trolley trucks. Perm Journal of Petroleum and Mining Engineering, 2018, vol.17, no.2, pp.166-180. DOI: 10.15593/2224-9923/2018.2.6

Просьба ссылаться на эту статью в русскоязычных источниках следующим образом:

Хазин М.Л., Тарасов А.П. Эколого-экономическая оценка карьерных троллейвозов // Вестник Пермского национального исследовательского политехнического университета. Геология. Нефтегазовое и горное дело. 2018. - T.17, №2. - C.166-180. DOI: 10.15593/2224-9923/2018.2.6 